\title{
AYDIN SANCAĞI TİRE KAZASINDA BULUNAN VAKIFLARIN 1275 (H.) TARİHLİ MUHASEBE DEFTERI
}

$* * *$

\section{5 (H.) DATED ACCOUNTING BOOK OF THE WAQFS IN TIRE DISTRICT OF AYDIN STATE DISTRICT OF AYDIN STATE}

\author{
Prof. Dr. İsmail BEKCI \\ Süleyman Demirel Üniversitesi \\ İktisadi ve İdari Bilimler Fakültesi \\ İșletme Bölümü \\ ismailbekci@sdu.edu.tr \\ ORCID: 0000-0002-9862-737X
}

Dr. Öğr. Üyesi Ali APALI

Mehmet Akif Ersoy Üniversitesi Bucak Zeliha Tolunay Uygulamalı Teknoloji ve İşletmecilik Yüksekokulu Muhasebe ve Finansal Yönetim Bölümü aapali@mehmetakif.edu.tr

ORCID: 0000-0002-3521-0150

\section{$\ddot{\mathbf{O} z}$}

Başbakanlık Osmanlı Arşivleri'nde bulunan belgeler arasında vaklf muhasebesi ile ilgili belgeler arşiv içerisinde en fazla yer alan belgeler arasında yeralmaktadır. Bu belgelerden "Aydın Sancağı'na ait EV.5..15477" yer kodlu belge özelinde Osmanlı Devleti'nde vakıf muhasebesi çalışmanın konusunu oluştururken, belgenin transkripsiyonunun yapllarak elde edilen verilerin muhasebe tarihi disiplini çerçevesinde incelenmesi ise çalışmanın amacını oluşturmuştur. Araştırmada Tire Kazası Vakfi yer sınırı, 1275 (H.), (1859 M.) tarihi çalı̧̧manın zaman sınırı ve vakıf muhasebesi de çalı̧̧manın konu sınırı olarak belirlenmiştir. Söz konusu belge çözümlendiğinde, vakıfların gelirleri ve bu gelirlerden dellaliye, cabi, kâtip, müfettiş kesintilerinin yapıldı̆̆l, belgedeki kayıtların bazen müfredatlı bazen de icmal şeklinde muhasebe işlemlerinin yapılmasının yanında merdiven sistemi ile kayıtlanan belgede bazı muhasebe hatalarının da olduğu tespit edilmiştir.

Anahtar Kelimeler: Aydın Sancă̆g, Tire Kazasl, Vakıf Muhasebesi, Muhasebe Tarihi, Merdiven Yöntemi, Siyakat.

\begin{abstract}
In the Ottoman Archives of the Prime Ministry, most of the documents are the documents related to the waqf (foundation) accounting. From this document, Allen Became the HOME.5..The purpose of this study is to investigate waqf accounting in the Ottoman Empire, specifically examine the data obtained by transcribing the EV.5. 15477 numbered document belongs to Aydin State, within the framework of the accounting history discipline. In study, the field limit of the study is determined as the waqfs in the Tire District, the date limit is determined as 1275 (H.) (1859 M.) and the limit of the subject is also determined as waqf accounting. The transcript of the document revealed that the revenues of foundations and the deductions of the announcers, debt collectors, clerks and inspectors are included; and while some of the accounting records are detailed, others are shortened, and also some errors are found in the document recorded with a staircase method.
\end{abstract}

Keywords: Aydin State, Tire District, Waqf Accounting, Accounting History, Merdiban Method, Siyaqat. 


\section{Gíriş}

Osmanlı Devleti'nde vakıf müessesesi, yardımlaşma amacıyla ortaya çıkan ve sınırları içerisinde en yaygın olan sivil toplum kuruluşları olup, kuruluş aşamasından sonra faaliyetleri sonucu kendi gelirlerini kendileri elde ederlerdi. Asıl amaçları kar elde etmekten ziyade toplum yararına faaliyet gösteren vakıfların en temel gelir kaynaklarını Vezirler, Sultanlar veya önde gelen devlet adamları karşılamaktaydılar. Vakıfların gelirleri, temelde iki farklı gideri karşılamak için gerekliydi. Bunlardan birincisi, hizmet sunabilmek için amaca uygun olarak gerçekleştirmesi gereken faaliyetlere ait giderlerdir. İkincisi ise, vakıfların yönetim işleri ile ilgili giderleri ve personel giderleridir.

Vakıflarda gelir ve gider dengesinin korunması için, sistemli bir kayıtlama yapılmaktaydı. Kayıtlar, vakfın alacaklarını, harcamalarını, mahsuplarını, kiralamalarını genel olarak tüketim malzemelerini ve personele ödenen tutarlar gibi bilgileri barındırmaktaydı. Osmanlı Devleti'nde vakıf muhasebeciliği, merdiven yönteminin en basit şekliyle tutulmaktaydı. Bu bağlamda, vakıf muhasebeciliği bu çalışmanın konusunu oluştururken, 1859 (M.)-1275 (H.) tarihli Aydın Sancağı Tire Kazasında faaliyet gösteren vakıfların muhasebe kayıtlarının transkripsiyonunun yapılarak çözümlenmesi ve muhasebe tarihi disiplini anlayışı ile yorumlanması ise çalışmanın amacını oluşturmaktadır. Bu doğrultuda çalışmada öncelikle Osmanlı Devleti’nde merdiven yöntemi, siyakat yazı sistemi ve vakıf muhasebeciliği hakkında bilgiler aktarıldıktan sonra EV. 15477 kodlu defterin çözümlenmesi yapılmıştır.

\section{OSMANLI DEVLETI'NDE MUHASEBE SISTEMI}

\subsection{Merdiven Yöntemi}

Osmanlıda muhasebe mesleği bir devlet muhasebesi içerisinde gelişme göstermiştir. Merdiven yöntemi mesleğin gelişmesinde önemli rol oynamıştır. Bu yöntem ihtiyaca göre geliştirilerek uzun yıllar kullanılmışıı (Güvemli, 2014: 230). Aslında merdiven yöntemi ilk olarak Ortadoğu'da Abbasiler (1251-1353) tarafından kullanılmıştır. Abbasi devletinde Harun Reşid (766-809) döneminde ilk örnekler tespit edilmiştir. Abbasilerden İlhanlı Devleti'ne (1251-1353) geçen yöntemi en son Osmanlı Devleti (1299-1922) kuruluş yıllarından Tanzimat'a kadar kullanmıştır (Akçay, 2017:1878).

Merdiven yönteminde ana tutarların başa yazılması ve ana tutarı ortaya çıkaran diğer tutarların alt alta bir merdiven basamağı gibi yazılmasından dolayı merdiven adını almıştır. Yöntemin ismi İlhanlılar döneminde konulmuştur (Mazenderani, çev. Otar, 2013: 46). Merdiven yönteminin temel olarak başlangıç noktası, miktar usulünden, tutar usulüne geçilmesidir. Mükellefler ödeyecekleri vergiyi artık miktar biriminin yanında tutar ifadesi ile de ödeme şansına sahip olmuşlardır. Miktar usulünden tutar usulüne geçiş ile birlikte mali işlemlerin kayıt altına alınması ihtiyacı iyice gelişmiş ve merdiven yöntemi olarak bilinen sistem ortaya çıkmıştır. (Elitaş vd. 2008: 180).

Merdiven yönteminin temel özellikleri şu şekilde sıralanmaktadır (Elitaş vd. 2008: 181);

- Devletçilik egemen olan ülkelerde devlet muhasebesi için kullanılmıştır.

- Devletin gelirleri ve giderleri için vergi gelirlerinin toplanması ve harcanması esasına dayanmaktadir.

- Vergi gelirlerinin eyaletlerden alınması her eyaletin toplam vergi gelirlerinin ve vergi türlerinin alt alta yazılarak toplanması şeklinde gerçekleştirilir.

- Harcama türleri ve tutarlarının alt alta sıralanması esastır.

- Sistemin muhasebenin tahakkuk esasına göre çalışması esastır. Ancak tahakkuk maddesi yapılmadan işlemlerin yürütüldüğü bilinmektedir. Tahakkuk tutarı başka bir yerde takip edilmektedir.

- Sistem hem miktar ve hem de tutar yazmaya müsait bir yapıdadır.

- Devletin bir yıllık gelirlerinin tek bir kayıt ile yapılmasını sağlar.

Merdiven yönteminin özel kesimde kullanılma şansı çok fazla olmamıştır. Genellikle Ortadoğu ülkelerinde olduğu gibi Osmanlı'da da iktisadi yaşamda devletçilik anlayışı hakim olduğu için özel kesim (işletme), tacir ve tüccarlar düzeyinde kalmıştır ve gelişmiş bir muhasebeye ihtiyaç duyulmamıştır. Böyle bir ortamdaki işletmecilik anlayışı çerçevesinde gelişmiş bir muhasebe ortaya 
çıkmadığı için, merdiven yönteminin kullanımı da devlet muhasebesi ile sınırlı kalmıştır (Özerhan, 2013: 91). Ancak, devlet muhasebesinde kullanılan merdiven yönteminin vakıflarda kullanımı bu durumun tek istisnasıdır (Güvemli ve Güvemli, 2016: 17).

Osmanlı Devleti 1859 yılına kadar aralıksız merdiven yöntemini kullanmıştır. Bu yıllardan itibaren yönünü batıya çevirmeye başlayan ve yenilenme hareketlerinin baş göstermesi, özel sektörün canlanmaya başlaması gibi nedenlerden dolayı merdiven yöntemi terk edilmeye başlanmıştır. Merdiven yöntemine ait yazılı talimatlar ve uygulamalar çok fazla bulunmamaktadır. Olanlar da sınırlıdır. Bunun en önemli nedeni merdiven yönteminin öğretimi usta-çırak ilişkisi ile gerçekleşmesi idi.

Devlet içerisinde ilk olarak muhasebenin belirli bir düzene bağlanmaya başlanması 1850 yılındaki "Kanunname-i Ticaret" ile başlamaktadır. Bu kanun Fransa'da 1807 yılında yürürlüğe giren "Code de Commerce"in örnek alınması ile hazırlandığından muhasebe üzerinde Fransız etkisi görülmüştür (Özçelik, 2017: 399). 1879 yılında Maliye Bakanlığı'nın yeniden teşkilatlanması sonrasında çift taraflı kayıt ilkesi benimsenmiştir. Bu karar alınırken kayıtların bilimsel bir yönteme göre tutulması, yöntemin Fransız ve İngiliz kontrolünde olan ve Osmanlı İmparatorluğu'nun para basımını üstlenen Osmanlı Bankası'nın maliye bakanlığı ile aynı kayıt yöntemini kullanma zorunluluğu, kayıtların daha da ayrıntılı bir şekilde tutulmak istenmesi, sanayileşme çabaları, kapitülasyonların kaldırılması gibi nedenler etkili olmuştur (Sürmen, 2012: 6; Özçelik, 2017: 400).

\subsection{Siyakat}

Merdiven yöntemi, uzun yıllar devlet muhasebesinde kullanılmış bir yöntem olup, devlet muhasebesinde siyakat yazısı ile birlikte kullanılmıştır (Elitaş vd., 2008, 78). Siyakat, Arapça "siyak" ve "siyakat" sözleri "savk" kelimesinden türemiştir. Savk kelime manası ile hayvan gütme, ardından yürütme, ilerletme, takip etme, iterek sürme gibi anlamlara gelmektedir (Tosun ve Atai, 2015: 59). Siyakat yazısı, iki amaca hizmet etmiştir. Bunlardan birincisi devletin gelir ve gider bilgilerinin muhasebe kayıtlarından anlaşılmasının önüne geçilebilmesi, ikincisi ise az yere daha çok bilgiyi hızlı bir şekilde kayıt altına alınabilmesidir (Elitaş vd., 2008, 78).

Siyakat yazısı, Osmanlı'da resmi ve özellikle de mali işlerde kullanılan eski bir yazı türüdür. Defterlerde ve tezkirelerde görülen kısalık, anlamada güçlük ve bilgi sahibi tarafından rahat bir şekilde okunup anlaşıldığı bir yazıdır. İnce, iç içe girmiş, herekesiz ve dik şekilde yazıldığ 1 için çok fazla yazıları az yer kapsayarak çabuk yazılma özelliğine sahiptir. Uzmanları tarafından okunabilen ve çok eski tabirleri içinde barındıran yazının uzun hatlarla yazılmış olanları olduğu gibi, kısa şekillerle yazılmış olanları da bulunmaktadır (Aydemir ve Erkan, 2011: 166).

Siyakat Osmanlı Devleti öncesi devletlerinde de bir bilim dalı kabul edilerek (İlm-i Siyakat) muhasebe kayıtlarında kullanılmıştır. Siyakat yazısı, maliye idaresinin hesap işleri, devlet muhasebesi ile birlikte kullanılmış olmasına rağmen, zaman içerisinde anlam değişerek maliye kayıtlarında, tahrirlerde siyakat rakamlarıyla birlikte gelişmiş ve mali kayıtlara özgü bir yazı karakteri halini almıştır. Bu yazı karakterine de "Hatt-1 Siyakat" yani siyakat yazısı denmiştir. Siyakat teriminin muhasebe mesleği ile bütünleşmesi ve sonrasında yazı türü anlamında kullanılması, Osmanlı Türkleri zamanına rastladığ ifade edilmektedir (Öztürk, 1996: 19; Şensoy, 2014: 82).

Siyakat yazısının içerisinde siyakat rakamları da yer almaktadır. Bu rakamlara arap ülkelerde "Siyakat-i Arabi" İran'da "Hesab-1 Dinari” ya da "Ruküm-i Siyak" Hind Müslümanlarının "Rüküm" ismi ile bahsettikleri ve bu özellikli olan rakamların siyakat yazısı ile birlikte kullanıldığ anlaşılmaktadır. Siyakat yazı ve rakamlarının öne çıkan kullanım alanlarını şu şekilde sıralamak mümkündür (Erol vd. 2012: 229);

- Muhasebe öğretiminde muhasebe kayıt ve belge düzeninde,

- Devletin mali düzenini oluşturan kayit ve belgelerinde,

- Devletin tapu kayit ve belgelerinde,

- Dış işlerinin yazışmalarında 
Dolayısıyla siyakat yazısı, Osmanlı Devleti döneminde Maliye, Defterhane ve Vakıf teşkilatında kullanılmış resmi bir yazıdır. Osmanlı Devleti'nde siyakat yazısı ve rakamları; bilhassa mali idarenin muhtelif bürolarında kullanılmıştır. Türk mali idaresinde görev yapan memurlar, asırlarca bu yazı ve rakamları kullanmışlardır. Ortadoğu'dan Balkanlar'a, Kırım'dan Akdeniz'in güney sahillerine uzanan geniş bir coğrafya üzerinde devlete ait her türlü gelir ve gider kalemleri hep yazı ile kaydedilmiştir (Öztürk, 1994: 6).

\section{OSMANLI DEVLETI'NDE VAKIF MUHASEBESİ}

Vakıf kelimesi, "bir hizmetin gelecekte de yapılması için belli şartlarla ve resmi bir yolla ayrılarak bir topluluk veya bir kimse tarafından birakılan mülk, para" olarak tanımlanmaktadır (TDK, 2011: 2453). Ebu Hanife'ye göre ise vakıf, bir mal veya mülkünün aynını vakfın, yani vakfedenin mülkiyetinde tutmak, gelirin fakirlere ya da hayır yollarından birine harcamaktır (Semiz, 2016: 91). Dolayısıyla vakıf, bir şahsın menkul veya gayrimenkul malını kendi mülkünden çıkarıp menfaatini halkın yararı için ebedi olarak hapsetmesidir. Bu anlamda, vakıfla ilgili olarak düzenlenen belgeye ise "vakfiye" denir. Vakfı yapana "Vâkıf", vakfedilen mala da "mevkûf" denir. Vakfiyeler, Kadı huzurunda düzenlenir (Elitaş vd. 2008: 236-237). Vakıflar, toplum yararına ortaya çıkmış olan sosyal güvenlik kurumları gibidir. Vakıflar ile ilgili bilgilerin çoğunlukla elde edildiği arşiv belgeleri, vakıf muhasebe defterlerinden oluşmaktadır. Bu defterler, vakıfların esas olarak gelir ve giderlerinin kayıt altına alındığı defterler olup, bunun yanında vakıf muhasebe defterlerinden varlıklarının neler olduğunu, vakfın özkaynaklarını, vakfın varlıklarının elde edildiği kaynakların kimlerden ve ne kadar olduğunu öğrenmek de mümkündür.

Büyük ölçekli vakıflar daha çok Vezirler veya devlet adamları vasıtasıyla kurulmaktaydılar (Barkan, 1963: 240). Vakıflar eğitim, sağlık, dini ve kültürel alanlarda bir takım faaliyetleri yerine getirmekteydiler. Kurulan bu vakıflar, söz konusu faaliyetleri nedeniyle birtakım giderlere katlanırken, bu giderleri karşılayacak farklı gelir kaynakları da bulunmaktadır. Vakıf himayesinde bulunan tarlaların kira gelirleri, han, hamam, dükkân kiraları vb. vakıflara gelir sağlayan kaynaklar olmuştur. Devlet tarafından vakıfların düzenli gelirleri olması adına vakıflara meralar, geniş araziler, karyeler gibi gayrimenkuller bırakılmıştır (Ülker ve Toraman, 2012: 61).

Osmanlı Devleti'nde önemli bir sosyal güvenlik kurumu olarak faaliyet gösteren vakıfları, sadece toplumda ihtiyaç sahiplerine yardım eden kurumlar olarak kabul etmek ile sınırlı değildir. Vakıflar, aynı zamanda şehirlerin imarına katkı sağlayan, bir külliye içerisinde han, hamam, kütüphane, ibadethane, aşevi ve eğitim birimleri inşa edilmesine yönelik çalışmalar yürüten ayrıca faaliyetleri sırasında giderlerini karşılayabilmek amacı ile çarşı, fırın, değirmen, debbağhane, salhane gibi tesisleri hayata geçirerek işleten ve buralardan gelir de elden kurumlardı (Sırım, 2017: 185).

Osmanlı Devleti'nde vakıfların sağlıklı bir şekilde uzun süreler faaliyette kalabilmeleri iki nedene dayandırılmaktadır. Bunlardan birincisi sağlam bir hukuki yapıya sahip olmaları ikincisi ise düzenli ve disiplinli bir muhasebe ve kayıt sistemi ile denetimine sahip olmalarıdır. Vakıflarda ortaya çıkan bu düzen, onların sürekli muhasebe denetimi altında tutulmalarına neden olmuştur (Güvemli ve Güvemli, 2016: 10). Bununla birlikte, vakıf muhasebeciliği çok karışık ve zor bir muhasebe ve kayıt sistemine sahip değildir. Bunun nedenlerinin başında devlet sınırları içerisinde sayı bakımından fazlaca bulunan vakıfların muhasebesini tutan kişilerin yaptığı kayıtların vakıf ilgilileri tarafından kolaylıkla anlaşılabilmelerinden kaynaklanmaktadır. Çünkü vakıf kayıtları, sadece muhasebeciler tarafindan değil, aynı zamanda onu denetleyen ve onaylayan kişiler tarafindan da anlaşılması gerekmektedir. Dolayısıyla vakıf muhasebesi, ilgili taraflar açısından açık, net, şeffaf ve anlaşılabilir olarak kayıt altına alınmakta ve yürütülmekteydi. Diğer yandan muhasebe bilgilerinin devlet sırrı niteliğinden ziyade daha çok ilgili tarafları ilgilendirmesi de bu durumun ortaya çıkmasının bir diğer sebebidir.

Osmanlı Devleti, vakıf muhasebeciliğinde ihtisas isteyen muhasebe teknikleri yerine kolay bir muhasebe kayıt sistemi kullanılmasını benimsemiştir. Örneğin, ilk önce vakfın sermayesi guruş para cinsinden yazılmış, bunun altına günlük olarak gider ve gelir rakamları ve karşılarına da açıklamaları yazılmıştır. Gelir mahiyetindeki tutar sermaye ile toplanarak, giden tutar ise çıkarılarak sonuç alt 
satırda gösterilmiştir. Böylece vakfın son hesap durumu hemen ilk bakışta görülebilmektedir (Kurt, www.isav.org.tr).

Vakıf faaliyetlerinin devam edebilmesi açısından gelir ve giderlerinin disiplinli ve sistemli bir şekilde kayıt altına alınmasının hesap verilebilmesi, tam açıklama, şeffaflık gibi kavramlar açısından belirli dönemlerde raporlanması ve denetlenmesi son derece önemlidir. Osmanlının özelikle bu konulara yönelik geliştirdiği yöntem, merdiven yöntemi'dir (Can ve Zeytin, 2010, 485).

Vakıf defterlerinin gelirler tarafi, hesapların ilgili olduğu cari yılda vakfın elinde bulundurduğu gelir kaynaklarının dökümünü ve bu kaynaklardan elde edilen gelirlerin her birinin vakfın toplam gelirleri içerisindeki oranlarını da ortaya çıkartabilmektedir. Vakıfların gelirlerini elde etmek için gelir kaynaklarını nasıl işlettiklerini, cari yılda gelirlerden fiili tahsilat miktarlarını ve alacaklı kalınan tutarları da görmek söz konusudur (Orbay, 2005: 39).

\section{15477 NOLU DEFTERIN ÇÖZÜMLENMESI}

Çalışmaya konu olan Başbakanlık Osmanlı arşivleri evkaf defterlerinden olan belge, EV.d.../15477-00 kodlu ve 07.06.1275 (H.) (12 Ocak 1859 M.) tarihli defterin başlangıç tarihi 1270, (1854 M.) bitiş tarihi ise 1275 (1859 M.) y1lı olarak kayıtlanmıştır. Söz konusu Defter, orijinalinde $21 \mathrm{x} 52 \mathrm{~cm}$ ebatlarında ve ciltli iken, yıpranmadan dolayı cildin bulunmadığı ifade edilmiştir. Varak düzenine göre kayıtlanan defter, toplam 4 varaktan oluşmaktadır.

Osmanlı Devleti vakıflarının muhasebe kayıtları, içerisinde farklı bölümleri içeren bir takım belgeler bulunmaktadır. Ancak bu belgeler, çoğunlukla vakfın bulunduğu yerin, vakfın adının, mütevellisinin, mahiyetinin, kayıtların tutulduğu zamanı (tarih) ve vakfın künyesini ifade edilen bilgiler olarak ortaya çıkmaktadır. Bu bölüme vakfın künyesi de denilmektedir (Durmuş ve Bektaş, 2017: 199). Çalışma konusu belgenin transkripsiyonu yapıldı̆̆ında vakfın künyesinin, "Aydın sancağ kazalarında bulunan evkaf-ı şerifelerin rüyet olunan muhasebeleriyle mazbut ve mülhakat-ı evkafin $v u k u$ bulan mahlulat ${ }^{1}$ ve ferağ ve intikalatlarının zirde muharrer defteridir" ş̧eklinde olduğu belirlenmiştir. Defterin içerisinde yer alan muhasebe kayıtlarının geleneksel merdiven yöntemi kullanılarak hazırlandığı görülmüştür. Birinci varakta yer alan ilk muhasebe kaydının bilgisi ise şu şekildedir; "Nezaret-i mezkurede evkaf-ı şerifelerin yetmiş senesine mahsuben rüyet olunan muhasebatın miktarl"

Tablo 1'de kayıtlı olan bilgiler, vakıfların $1270 \mathrm{H}$. senesine ait tespit edilen tutarların mahsup kayıtlarını içermektedir.

Tablo 1. Evkafların 1270 Senesinin Mahsub Kayıtları

\begin{tabular}{|l|c|}
\hline \multicolumn{1}{|c|}{ Vakıf Adı } & Tutar (Guruş) \\
\hline Vakf-1 Behram Kethüda & 050 \\
\hline Vakf-1 Hafize Hatun & 450 \\
\hline Vakf-1 Hacı Mehmed Ali Ağa & 680 \\
\hline Vakf-1 Şehri? Ahmed Bey & 300 \\
\hline Vakf-1 Yahya Bey & 173 \\
\hline (Ara Toplam) ${ }^{2}$ & $\mathbf{1 6 5 3}$ \\
\hline Vakf-1 Hafza Hatun Bint-i Aydın Bey & 3000 \\
\hline Vakf-1 Hazret-i İbn-İ Melik & 0680 \\
\hline Vakf-1 Ayaş? Bey & 0600 \\
\hline Vakf-1 Küçük Hafiz & 0020 \\
\hline Vakf-1 Timur Ağa & 0130 \\
\hline (Ara Toplam) & $\mathbf{6 0 8 3}$ \\
\hline Vakf-1 Hafize/Hafza Hatun & 1775 \\
\hline Vakf-1 Ma-1 Leziz-1 Celaleddin & 0021 \\
\hline Vakf-1 Arnavut Kadın? & \\
\hline Vakf-1 Kara Hayreddin & \\
\hline Vakf-1 Kariz-Zade? & \\
\hline (Ara Toplam) & \\
\hline Vakf-1 Kara Pınarı & 0100 \\
\hline Vakf-1 Lütfi Paşa & \\
\hline
\end{tabular}

\footnotetext{
${ }^{1}$ Mirasçısı olmayan kişilerin evkafa kalan mirası.
}

${ }^{2}$ Çalışmada "( )" şeklinde yazılan açıklamalar tarafımızca ifade edilmiştir. Belgede bu tutarlarla ilgili bir açıklama kaydı söz konusu değildir. 


\begin{tabular}{|l|c|}
\hline Vakf-1 Hasan Çelebi & 0180 \\
\hline (Ara Toplam) & $\mathbf{1 0 7 0 4}$ \\
\hline Vak-F Hacı Sinan? & 00250 \\
\hline Vakf-1 Bazari-Zade & 00007,5 \\
\hline Vakf-1 Nükud-i (.....) & 00135 \\
\hline Vakf-1 Mehmed Ağa & 00200 \\
\hline Vakf-1 Cami-i Kebir & 00000 \\
\hline (Toplam) & $\mathbf{1 1 2 9 6 , 5}$ \\
\hline
\end{tabular}

Tablo 1'e göre, Osmanlı Devleti vakıflarında mahsup işlemlerinin de gerçekleştiği belgelerden anlaşılmaktadır. Tahsil edilemeyen gelirler, bir sonraki yıla ya da yıllara aktarılmaktadır. Belgenin başında verilen toplam 23 adet vakfa ait kayıtların, alt alta bir merdiven anlayışı ile yazıldığı ve belirli aşamalarda ara toplamları alındığı için Osmanlı Devleti muhasebe kayıt sistemi olan merdiven yöntemine göre muhasebeleştirildiği anlaşılmaktadır.

Birinci aşamada 1.653-, ikinci aşamada 6.083-, üçüncü aşamada 8.104-, dördüncü aşamada 10.704- ve son aşama olan beşinci aşamada ise mahsup edilen tutarın 11.896,5- kuruş olduğu görülmektedir. Belgede yer alan kayıtlar incelendiğinde herhangi bir muhasebe kayıt hatasına rastlanılmamıştır.

Vakıf muhasebeciliğinde vakıfların gelirlerinin kaydedildiği bölüm irad bölümüdür. Vakıfların sürekli olarak gelir elde ettiği kaynaklar vakfın konusuna göre genelde ikiye ayrılmaktadır. Bunlardan birincisi, vakıflarda nakit olarak bulunan sermayenin işletilmesinden elde edilen gelirlerdir. İkincisi ise sahip olunan gayrimenkullerin kiraya verilmesinden elde edilen gelirlerden oluşmaktadır. Bunların dışında vakıfların icareteynle kiraya verilen mülklerin mahlül $1^{3}$ olması durumunda yeniden kiraya verilmesinden elde edilen muaccele ${ }^{4}$ gelirleri ve teberru ${ }^{5}$ gibi sürekli olmayan gelir kalemleri de bulunmaktadır (Durmuş ve Bektaş, 2017: 200). Çalışmaya konu olan belgede ise irad kayıtları yer almaktadır. Buna göre birinci varağın devam eden kayıtlarının açıklaması şu şekildedir; "Mülhakat-1 evkaftan vuku bulan mahlulatın miktarı". Aşağıdaki Tablo 2'de mirasçısı olmayanların vakıflara kalan mirasları gösterilmiştir.

Tablo 2. Vakıfların Mahlulat Kayıtları

\begin{tabular}{|c|c|c|c|c|c|}
\hline \multirow[b]{2}{*}{ Açıklama } & \multirow{2}{*}{$\begin{array}{c}\text { Muaccele }^{6} \\
\text { Kuruş }\end{array}$} & \multicolumn{4}{|c|}{ Mürettebat $^{7}$} \\
\hline & & Rub $^{\text {, }}$ & Resm? & $\begin{array}{c}\text { Nisf-1 } \\
\text { Dellaliye }^{10}\end{array}$ & Toplam \\
\hline $\begin{array}{l}\text { Hoca Kemal mahlûl-1 bir bab kahve talibi Hacı Ali } \\
\text { uhdesinde kararı }\end{array}$ & 2700 & $\begin{array}{c}577 \text { kuruş } \\
5 \text { para }\end{array}$ & 135 kuruş & 027 kuruş & $\begin{array}{c}739 \text { kuruş } \\
5 \text { para }\end{array}$ \\
\hline $\begin{array}{l}\text { Memiş Bey mahlül-1 dükkân talibi Ali Efendi uhdesinde } \\
\text { kararı }\end{array}$ & 3500 & $\begin{array}{l}748 \text { kuruş } \\
5 \text { para }\end{array}$ & 175 kuruş & 035 kuruş & $\begin{array}{l}958 \text { kuruş } \\
5 \text { para }\end{array}$ \\
\hline $\begin{array}{l}\text { Lütfi Paşa mahlül-1 dükkân-1 Dervişzade, talibi Mustafa } \\
\text { Efendi uhdesinde kararı }\end{array}$ & 1800 & $\begin{array}{c}384 \text { kuruş } \\
5 \text { para }\end{array}$ & 090 kuruş & 018 kuruş & $\begin{array}{c}492 \text { kuruş } \\
10 \text { para }\end{array}$ \\
\hline $\begin{array}{l}\text { Yahşi Bey mahlûl an Duhanizade Mehmed Ağa, talibi } \\
\text { Hasan Efendi uhdesinde kararı }\end{array}$ & 4850 & $\begin{array}{c}1036.5 \text { kuruş } \\
10 \text { para }\end{array}$ & 0242.5 kuruş & 048 kuruş & $\begin{array}{l}1327 \text { kuruş } \\
10 \text { para }\end{array}$ \\
\hline $\begin{array}{l}\text { Yahşi Bey mahlül-1 Kara Hacızade Mehmed Ağa tarlası } \\
\text { talibi Gülcüzade Mehmed Efendi uhdesinde kararı }\end{array}$ & 1200 & 261 kuruş & 060 kuruş & 012 kuruş & 333 kuruş \\
\hline $\begin{array}{l}\text { Bey mahlul-1 dükkan-1 (....) sebzeci talibi hacı Mehmed } \\
\text { uhdesinde kararı }\end{array}$ & 1500 & $\begin{array}{l}330.5 \text { kuruş } \\
5 \text { para } \\
\end{array}$ & 075 kuruş & 015 kuruş & $\begin{array}{l}320.5 \text { kuruş } \\
5 \text { para }\end{array}$ \\
\hline $\begin{array}{l}\text { Hafsa Hatun mahlül tarla-ı dervişzade, talibi Mustafa } \\
\text { Efendi uhdesinde kararı }\end{array}$ & 4100 & $\begin{array}{l}876 \text { kuruş } \\
10 \text { para }\end{array}$ & $\begin{array}{c}205 \text { kuruş } \\
05 \text { para }\end{array}$ & 041 kuruş & $\begin{array}{l}1122 \text { kuruş } \\
15 \text { para }\end{array}$ \\
\hline $\begin{array}{l}\text { Mühür? Ahmed Bey, mahlûl tarla talibi uncuzade halilesi } \\
\text { Âmine Hatun uhdesinde kararı }\end{array}$ & 1100 & $\begin{array}{l}235 \text { kuruş } \\
10 \text { para }\end{array}$ & 055 kuruş & 011 kuruş & $\begin{array}{l}301 \text { kuruş } \\
5 \text { para }\end{array}$ \\
\hline $\begin{array}{l}\text { Yahşi Bey, mahlûl tarla-1 Dervişzade, talibi Mustafa Efendi } \\
\text { uhdesinde kararı }\end{array}$ & 1700 & $\begin{array}{l}363 \text { kuruş } \\
15 \text { para }\end{array}$ & 075 kuruş & 017 kuruş & $\begin{array}{l}465 \text { kuruş } \\
15 \text { para }\end{array}$ \\
\hline $\begin{array}{l}\text { Yahşi Bey mahlül-1 dükkân, hisse-1 Etmekçi, talibi Dimitri } \\
\text { uhdesinde kararı }\end{array}$ & 3300 & 705.5 kuruş & 165 kuruş & 033 kuruş & 903.5 kuruş \\
\hline
\end{tabular}

\footnotetext{
${ }^{3}$ Mahlüllük: Vakıf hukukunda mahlüliyet, icareli ve mukataalı vakıf malları kullanma hakkına sahip olanların gaip, firari olmaları veya altsoy (füru) bırakmadan ölmeleri halinde bu malların mülkiyetinin vakfa rücuunu ifade etmektedir (Aksoy, 1995: 87).

${ }^{4}$ Muaccel: Peșin, hemen ödenen.

5 Teberrü: Bağış

${ }^{6}$ Beylik ve evkaf kiralarından peşin alınan kısım.

${ }^{7}$ Mürettebat: Tertip edilen, bir iş için görevlendirilen

${ }^{8}$ Dörtte bir.

${ }^{9}$ Vergi, devlet adına alınan.

${ }^{10}$ Tellaliye parasının yarısı.
} 


\begin{tabular}{|l|c|c|c|c|}
\hline $\begin{array}{l}\text { Mescid-1 Musluhiddin? mahlül-1 dükkan-1 Mehmed Ağa, } \\
\text { talibi-1 Hacı Halil uhdesinde kararı }\end{array}$ & 1700 & $\begin{array}{c}363 \text { kuruş } \\
15 \text { para }\end{array}$ & 075 kuruş & $\begin{array}{c}017 \text { kuruş } \\
15 \text { para }\end{array}$ \\
\hline Yekün & $\begin{array}{c}7527.5 \text { kuruş } \\
15 \text { para }\end{array}$ \\
\hline
\end{tabular}

Tablo 2'ye göre, rub, resm ve nısf-1 delaliye bedelleri de vakıf defterlerinde kayıt altına alınmış olup, bunların toplamı da belgede 7527,5 kuruş ve 15 para olarak yer almıştır.

Belgenin ikinci sayfasında bazı tarlalarının miktarları ve peşin alınan bedellerine ait kayıtlar yer almaktadır. Belgede bu husus "Kaza-ı mezkûrda vaki mazbut evkaftan cennet-mekân sultan selim han tabe-serahu hazretlerinin darülkurra evkaf-ı şerifi arazilerinden vukubulan mahlulat bi'l-müzayede füruht olunan tarlahanın miktarı" şeklinde kayıtlanmıştır. Belgenin devam eden kısımda tarlaların miktar ve kiralarının transkripsiyonu aşağıdaki Tablo 3 ’te görüldüğü gibidir.

\section{Tablo 3. Tire Kazasındaki Bazı Tarlaların Miktar ve Kira Bedelleri}

\begin{tabular}{|c|c|}
\hline Açıklama & $\begin{array}{c}\text { Muaccele } \\
\text { (Kuruș) }\end{array}$ \\
\hline $\begin{array}{l}\text { Kaza-1 mezkûrdan sekiz dönüm bir kıt’a tarlaya mutasarrıf olan Koca Mustafa oğlu Ali fevt olup, biraderi Ali } \\
\text { uhdesinde kararı }\end{array}$ & 600 \\
\hline $\begin{array}{l}\text { Vakf-ı mezkûrdan beş dönüm tarlaya mutasarrıf olan Molla Memiş fevt olup, mahlûlünden Yafe karyeli Hacı Himmet } \\
\text { uhdesinde kararı }\end{array}$ & 2000 \\
\hline $\begin{array}{l}\text { Vakf-1 mezkûrdan beş dönüm tarlaya mutasarrıf olan Kassab zevcesi Fatıma müteveffiye olmakla mahlûlünden Kara } \\
\text { Ali uhdesinde kararı }\end{array}$ & 580 \\
\hline $\begin{array}{l}\text { Vakf-1 mezkûrdan yirmi dönüm bir kıt’a tarlaya mutasarrıf olan Kara Hacı oğlu Mehmed Ağa fevt olub, mahlûlünden } \\
\text { Hacı Şerifzade Süleyman Efendi uhdesinde kararı }\end{array}$ & 3000 \\
\hline $\begin{array}{l}\text { Vakfi mezkûrdan altı dönüm bir kıt'a tarlaya mutasarrıf olan Emine Hatun müteveffiye olub, mahlûlünden Terzizade? } \\
\text { ve biraderi Hüseyin Efendi uhdesinde kararı }\end{array}$ & 2050 \\
\hline $\begin{array}{l}\text { Vakf-1 mezkûrdan beş dönüm bir kıt’a tarlaya mutasarrıf olan Zabun Arab oğlu Mehmed fevt olub, mahlülünden } \\
\text { zevcesi Âmine Hatun uhdesinde kararı }\end{array}$ & 700 \\
\hline $\begin{array}{l}\text { Vakf-1 mezkûrdan beş dönüm bir kıt’a tarlaya mutasarrıf olan Yörük Osman oğlu Osman fevt olup mahlûlünden } \\
\text { biraderi Mehmed uhdesinde kararı }\end{array}$ & 200 \\
\hline $\begin{array}{l}\text { Vakf-1 mezkûrdan bir kıt'a tarlaya mutasarrıf olan Yörük Osman oğlu Osman fevt olup biraderi Osman Çavuş } \\
\text { uhdesinde kararı }\end{array}$ & 300 \\
\hline $\begin{array}{l}\text { Vakf-1 mezkûrdan altı dönüm bir kıt’a tarlaya mutasarrıf olan Hacı Celil oğlu Mustafa fevt olup mahlûlünden Hamza } \\
\text { Ali Oğlu Mustafa'ya uhdesinde kararı. }\end{array}$ & 1750 \\
\hline $\begin{array}{l}\text { Vakf-1 mezkûrdan bir kıt'a tarlaya mutasarrıf olan Yaka karyeli Arab Kara Mehmed fevt olub mahlûlünden Bayındırlı } \\
\text { Hacı Ali oğlu Mustafa uhdesinde kararı }\end{array}$ & 1500 \\
\hline $\begin{array}{l}\text { Vakf-1 mezkûrdan bir kıt’a on beş dönüm tarlaya mutasarrıf olan Mücellid oğlu İsmail fevt olup mahlûlünden talibi } \\
\text { Kelesli? Ali uhdesinde kararı }\end{array}$ & 1900 \\
\hline Ceman Yekün & 14580 \\
\hline Ba-berat katib ve cabi efendilere verilen & 00364.5 \\
\hline (Kalan) & 14215.5 \\
\hline Dellaliye ve ihbariyesi & 00291 \\
\hline$(\text { Kalan })^{11}$ & 13924.5 \\
\hline
\end{tabular}

Tablo 3'te Darülkurra ${ }^{12}$ evkafı arazilerinin miktarları karşıllı̆ında kira bedelleri gösterilmiştir. Tarla kiralarının toplamı 14.580- kuruş olarak muhasebeleştirilmiştir. Bu gelirden 364,5- kuruş kâtip yani dönemin muhasebecisine ve cabi efendiye yani günümüz karşılığı ile tahsildara ödenmiştir. Bu iki çalışana yapılan ödeme sonrasında belgede tekrar bir (ara) toplam alınmış ve bu toplam da 14.215,5kuruş olarak kaydedilmiştir. Belgenin bu kısmında ayrıca dellaliye (tellaliye) ve ihbariye (haber verme ücreti ve yazılı evrak bedelleri olan 291- kuruşluk gider de ara toplamdan düşülerek genel toplam olan 13.924,5- kuruşa ulaşılmıştır. Belgede bahsi geçen tarlalar farklı kişilerin uhdesinde ve genel olarak dönüm ve kıt'a ölçü birimleri ile ölçeklendirilmiştir. Her bir tarlanın birim başına düşen gelirlerinin farklı olduğu da belgeden ayrıca tespit edilmektedir.

Aşağıda yer alan Tablo 4'te, Tire kazasında bulunan bazı vakıfların feră̆ ve intikalleri ile ilgili muhasebe kayıtları gösterilmiştir.

\footnotetext{
${ }^{11}$ Giderler düşüldükten sonra kalan tutar.

${ }^{12}$ Kur'an öğretilen ve hafız yetiştiren okulların genel adı.
} 
Tablo 4. Mülhakat-ı Evkaftan Vukubulan Ferağ ${ }^{13}$ ve İntikalatın Miktarı.

\begin{tabular}{|c|c|c|}
\hline Açıklama & $\begin{array}{l}\text { Bedel } \\
\text { Kuruş }\end{array}$ & $\begin{array}{l}\text { (Harcı) } \\
\text { Kuruş }\end{array}$ \\
\hline An vakf-1 Kazirzade rub' kahve ferağından Şerbetçizade Ahmed Efendiye kasr-1 yed & 1500 & 22,5 \\
\hline An vakf-1 Hasan Çelebi Keçeci Bekir kerimeleri ferağından bağ & 4000 & 100 \\
\hline An vakf-1 karizzade bir kıt’a dükkân ferağından & 1000 & 015 \\
\hline $\begin{array}{l}\text { An vakf-1 Hafsa hatun ibnitihi Aydın Bey. Keçeci Bekir kerimeleri rızasıyla Meşincizade? Hacı } \\
\text { Ahmed Ağa'ya kasr-1 yeddir. Tarla dönüm } 8\end{array}$ & 2000 & 050 \\
\hline $\begin{array}{l}\text { An vakf-1 Hasan Çelebi bir bab dükkâna mutasarrıf olan Deli Ali rızasıyla Mustafa'ya kasr-1 yed } \\
\text { etmiştir. }\end{array}$ & 1200 & 009 \\
\hline (Ara Yekün) & 0000 & 196,5 \\
\hline $\begin{array}{l}\text { An vakf-1 Yahşi Bey bir kıt'a tarlaya mutasarrıf olan Şerif Ahmed rızasıyla Gülcüzade Mehmed } \\
\text { Efendi'ye kasr-1 yed etmiştir. }\end{array}$ & 3500 & 82,5 \\
\hline $\begin{array}{l}\text { An vakf-1 ibn-1 melek bir kıt'a tarlaya mutasarrıf olan Kostati rızasıyla Mustafa ile zevcesi Güllü } \\
\text { Hatun'a kasr-1 yed etmiștir. }\end{array}$ & 1800 & 45 \\
\hline $\begin{array}{l}\text { An vakf-1 Hasan Çelebi, bir bab dükkana mutasarrıf olan Aişe Hatun rızasıyla Şerif Ahmed'e kasr-1 } \\
\text { yed etmiştir. }\end{array}$ & 1000 & 15 \\
\hline $\begin{array}{l}\text { An vakf-1 Cami-1 Tahtakale, bir bab hana mutasarrıf olan Ahmed Ağa rızasıyla Ali Kiiseli oğlu Hacı } \\
\text { Mehmed'e kasr-1 yed etmiştir. }\end{array}$ & 10500 & 157 \\
\hline (Toplam) & 00000 & 496 \\
\hline
\end{tabular}

Tablonun ilk sütunu kayıtlarda yer alan vakfiyelerin neler olduğunu, ikinci sütunu intikal eden mülkün tutarını ve üçüncü sütun ise ferağ bedelini göstermektedir. Belgede, önce ferağ bedelleri ara toplam olarak 196,5- kuruş sonrasında ise 496- kuruş olarak merdiven sistemi ile yekün olarak hesaplanmıştır. Ancak, yine belgede intikal bedellerinin toplanmadığı, sadece bedel olarak verildiği görülmektedir. Tablo 4'teki ferağ bedellerini, binalar ve araziler olarak ikiye ayırmak mümkündür. Belgede genel olarak bina bedellerinden binde on beş, arazi bedellerinden ise binde yirmi beş oranında ferağ hesaplandığı görülmektedir. Sadece istisna olarak Hasan Çelebi Vakfı mülhakındaki bir dükkânın ferağ bedeli binde sekiz olarak kayıt altına alındığı tespit edilmiştir.

Belgenin devam eden kısımda Sultan Selim Han'a ait arazilerin ferağ ve intikallerinin kayıtları yer almaktadır. Bunlar "Mazbut evkaftan cennet mekân Firdevs Aşiyan Sultan Selim Han hazretlerinin kaza-ı mezkûrda olan arazilerinin ferağ ve intikallerinin miktarını mübeyyin defteridir" şeklinde bir başlık altına alınmıştır.

Tablo 5'te Sultan Selim Han'a ait arazilerin ferağ ve intikal bedellerine ait bilgiler yer almaktadır.

Tablo 5. Sultan Selim Han’a Ait Arazilerin Ferağ ve İntikal Bedelleri

\begin{tabular}{|l|c|c|}
\hline \multicolumn{1}{|c|}{ Açıklama } & $\begin{array}{c}\text { Barcı } \\
\text { Kuruş }\end{array}$ & \multicolumn{1}{c|}{ Kuruş } \\
\hline Bir kıt'a tarlaya mutasarrıf olan Molla Süleyman rızasıyla Bayındırlı Tiralı? Oğlu Kostatiye kasr-1 y ed etmiştir & 1500 & 75 \\
\hline $\begin{array}{l}\text { Bir kıt'a tarlaya mutasarrıfe olan Aydınlı Mehmed Efendi zevcesi Raziye Hatun rizasıyla Hindli damadı Hasan } \\
\text { Efendi'ye kasr-1 yed etmiştir. }\end{array}$ & 2500 & 125 \\
\hline $\begin{array}{l}\text { Bir kıt'a tarlaya mutasarrıf olan Aydınlı Mehmed Efendi zevcesi Raziye Hatun rızasıyla Hindli damadı Hasan } \\
\text { Efendiye kasr-1 yed etmiştir. }\end{array}$ & 2500 \\
\hline
\end{tabular}

\footnotetext{
${ }^{13}$ Osmanlı hukukunda miri ve icareteyn'li vakıf malları üzerinde şahıslar için mülkiyet hakkına benzer bir tasarruf hakkı tesisine imkan verilmiş, ferağ da bu tasarruf hakkının başka bir kişiye terk ve devrini ifade eden bir terim olarak kullanılmıştır. (http://www.islamansiklopedisi.info/dia/pdf/c12/c120199.pdf)
} 
Bir kıt'a bağa mutasarrıf olan Mustafa fevt olup bağ-1 mezkûr oğlu Halil'e intikal etmiştir.

Bir kıt'a tarlaya mutasarrıf olan Hacı Köse rızasıyla Elikıllı? Osman'a kasr-1 yed etmiștir.

Bir kıt'a tarlaya mutasarrıf olan Barmiyeli? Mustafa rızasıyla Koca Ahmed kerimesi Âmine Hatun'a kasr-1 yed etmiş̧tir.

Bir kıt'a tarlaya mutasarrıf olan Karaoğlan oğlu Mustafa rızasıyla Küçük Mustafa oğlu Mehmed Ali’ye kasr-1 yed etmiş̧tir.

Bir kıt'a tarlaya mutasarrıf olan Şavlığlu Hacı Mehmed fevt olup evladlarına intikal etmiștir.

Bir kıt'a tarlaya mutasarrıf olan Sollu Hüseyin rızasıyla Dere karyeli Molla Hüseyine kasr-1 yed etmiştir.

Bir kıt'a tarlaya mutasarrıf olan Nane Molla oğlu Molla Mehmed rızasıyla Hacı Şerifzade Süleyman Efendi'ye kasr-

1 yed etmiştir.

Bir kıt'a tarlaya mutasarrıf olan Fındıkoğlu Ligori rızasıyla Abdullah bin Mehmed'e kasr-1 yed itmişstir.

Bir kıt'a tarlaya mutasarrıf olan Fındık oğlu Ligori ve İstalbakoz? Rızasıyla Abdullah bin Mehmed'e kasr-1 yed

etmiş̧tir.

Bir kıt'a tarlaya mutasarrıf olan Fatma Hatun ibnit-1 Mehmed rızasıyla Kazıkçızade Hacı Mehmed efendi’ye kasr-1 yed etmiştir.

Bir kıt'a tarlaya mutasarrıf olan Sarı Kadı rızasıyla Emrullah oğlu Mustafaya kasr-1 yed etmiştir.

Bir kıt'a tarlaya mutasarrıf Şerife Hatun rızasıyla Yörük Koca Molla oğlu Hüseyin'e kasr-1 yed etmiștir

Bir kıt'a tarlaya mutasarrıf olan Hacı Hüseyin Efendi rızasıyla Bayındırlı Kostati'ye kasr-ı yed etmisștir.

Bir kıt'a tarlaya mutasarrıf olan Yahudi Balbami rızasıyla Baba Yorgi'ye kasr-1 yed etmiş̦tir.

Bir kıt'a tarlaya mutasarrıf olan Katmerci Hüseyin rızasıyla Mustafa ali Ağa'ya kasr-1 yed etmiștir.

Bir kıt'a tarlaya mutasarrıf olan Kerime-1 Habib? Fatma Hatun rızasıyla Sarhallı? Oğlu Hüseyine kasr-1 yed etmiştir.

Üç kıt'a tarlaya mutasarrıf olan Kara Mihal ve Deveci Kocaman oğlu mustafa ve Şemhaneci oğlu Mustafa rızasıyla

Dimidinoğlu Yorgiye kasr-1 yed etmiş̧tir

Bir kıt'a tarlaya mutasarrıf olan Nalband Mistakoğlu Mehmed rızasıyla Gülcüzade mehmed Efendi’ye kasr-1 yed etmiştir.

Bir kıt'a tarlaya mutasarrıf olan Burgazi Mehmed kerimesi Aişe Hatun rızasıyla Gülcüzade Mehmed Efendi'ye kasr1 yed etmiştir.

Yine bir kıt'a tarlaya mutasarrıf olan Karcızade Hacı Mehmed Efendi rızasıyla Gülcüzade Mehmed Efendi’ye kasr-1 yed etmiş̧tir.

Üç kıt’a tarlaya mutasarrıf olan Müftüzade Mehmed Efendi rızasıyla Gülcüzade Mehmed Efendi’ye kasr-1 yed etmiştir.

Bir kıt'a tarlaya mutasarrıf olan Ganadiyoz rızasıyla Abdullah'a kasr-1 yed etmiştir

Bir kıt'a tarlaya mutasarrıf olan Hacı Osman oğlu Mehmed zevcesi Hatice Hatun rızasıyla Bekaroğlu Ali’ye kasr-1

yed etmiştir

Bir kıt'a tarlaya mutasarrıf olan Musaoğlu Mehmed fevt [olup] evladları Ahmed ve Esma Hatun'a intikal etmiştir

Bir kıt'a tarlaya mutasarrıf olan Hacı Sadık Efendi rızasıla Hacı Veli ibn-1 Hacı Mehmed'e kasr-1 yed etmiștir.

Bir kıt'a tarlaya mutasarrıf olan İbram? Rızasıyla Çapkınoğlu Mustafa'ya kasr-1 yed etmiştir.

Bir kıt'a tarlaya mutasarrıf olan Hacı Ahmed rızasıyla Hacı Mehmed Ağa'ya kasr-1 yed etmiştir.

Bir kıt'a tarlaya mutasarrıf olan Uncuzade Hacı Mehmed rızasıyla Fahreddin Efendiye kasr-1 yed etmiştir.

Bir kıt'a tarlaya mutasarrıf olan uncuzade Hacı Mehmed rızasıyla Fahreddin Efendiye kasr-1 yed etmiştir.

Bir kıt'a tarlaya mutasarrıf olan Fatma hatun rızasıyla tebaadan Ali Ağaya kasr-1 yed etmiştir.

Yekün

Katib ve cabi hissesi

(Kalan)

Ceman Yekün

Mürettebatı Hasılat

Hisse-1 müdür-1 evkaf

(Kalan)

\begin{tabular}{|c|c|}
\hline 100 & 5 \\
\hline 500 & 25 \\
\hline 300 & 15 \\
\hline 230 & 11.5 \\
\hline 400 & 20 \\
\hline 400 & 20 \\
\hline 1500 & 75 \\
\hline 1500 & 75 \\
\hline 2000 & 200 \\
\hline 3000 & 150 \\
\hline 200 & 10 \\
\hline 1000 & 50 \\
\hline 1000 & 50 \\
\hline 600 & 30 \\
\hline 1000 & 50 \\
\hline 1100 & 55 \\
\hline 750 & 32.5 \\
\hline 1350 & 67.5 \\
\hline 4800 & 240 \\
\hline 2000 & 100 \\
\hline 4000 & 200 \\
\hline 500 & 25 \\
\hline 400 & 20 \\
\hline 500 & 25 \\
\hline 1000 & 50 \\
\hline 650 & 32.5 \\
\hline 300 & 15 \\
\hline 1500 & 75 \\
\hline 1500 & 75 \\
\hline 650 & 32.5 \\
\hline & 2161 \\
\hline & 540 \\
\hline & 1621 \\
\hline 34865,5 & \\
\hline 34865,5 & \\
\hline 2975 & \\
\hline 27890,5 & \\
\hline
\end{tabular}

Tablo 5'te söz konusu belgenin ikinci ve üçüncü varaklarındaki kayıtlarda Sultan Selim Han'in

Tire kazasındaki arazilerinin ferağ ve intikallerinin muhasebe kayıtları ve kayıtların transkripsiyonu yer almaktadır. Hem arazi bedelleri hem de harçlarının yer aldığ 1 tablodaki arazilerin ölçüm birimi kıt'a ile ifade edilmiştir. Belgeye göre arazilerin bedeli 34.865,5- kuruş olarak hesaplanmasından sonra vakıf müdürünün hissesi olarak 2.975- kuruş düşülmüş ve sonrasında 27.890,5- kuruş kalan olarak muhasebeleştirilmiştir. Diğer yandan harç bedellerinin toplamı ise 2.161- kuruş olarak hesaplanmıştır. 27890,5 guruşluk tutar vakıflar içerisindeki en yüksek tutarlı sultan vakfına aittir. Ayrıca vakıf gelirlerinin tamamı tarla gelirlerinden elde edildiği için aynı zamanda mukataalı vakıf olduğu ortaya çıkmaktadır.

Vakıf defterinde ayrıca muhasebeci (katip) ücreti yer almaktadır. Bu ücretler merkez muhasebecilerinin (merkez teşkilatında görev alan) ücretleri olmayıp, vakfın bulunduğu yerde muhasebesini yürüten, muhasebe görevini yerine getiren muhasebeciye (katibe) verilen ücrettir. Taşrada görev yapan bu muhasebeciler, günümüzde farklı şekillerde büroları olan ve bağımsız çalışan muhasebeciler gibidir (Güvemli ve Güvemli, 2016: 16). Ancak çalışmaya konu olan belgede, muhasebeci olarak görev alan kişinin ücreti cabi ile birlikte 540- kuruş olarak kayıt altına alındığ görülmektedir. 
Varağın sonunda bahsedilen kayıtlar sonrasında rakamla tutarın yazılması yanında bir de "yalnız yirmi yedi bin sekiz yüz doksan buçuk kuruştur" diye kalan tutar kaydedilmiştir. Mühürden nazırın varağı onayladığı "Evkaf nazırı", "Es-seyyid Abdurrahman el-müvella-el-hilafetihi be-medine-ı Güzelhisar-ı Aydın be-müftii'l- el-hakir ed-dai (...)" ve (Mühür) "Seyyid Abdurrahman" ismiyle de mühürlendiği", "Tatbik ve hesab birle iktizası varidattan", "İ̧ bu mahall tatbik olunduğundan canib-ı yesara derkenar şode" Kayıtlarıyla da belgenin bu kısmı kapatılmıştır.

Belgenin devam eden kısmında (varak 3-a) "Bera-yı hasılat-ı harç-l feră̆ ve intikalat ve muaccelat-ı mahlulat-ı an vakf-ı şerif-ı Sultan Selim Han der kaza-ı Tire der liva-ı Aydın an makbuz-ı hazine-ı evkaf-ı hümayun vacib der sene [boşluk] der zaman-ı Bekir Usta Müdir-ı Evkaf-ı Liva-ı Sabık ber muceb-ı mümzü defter-ı müfredat ve ba-ferman-ı sami", "Bera-yı hasılat-ı muaccelat-ı mahlulat an vakf-ı müşarunileyh der kaza-ı m. der liva-ı m." Şeklinde bir kayıt bulunmaktadır. Buna göre peşinen ödenmesi gereken Tire Kazası'ndaki arazilerin bedellerinin aşağıdaki Tablo 6'daki gibi muhasebeleştirildiği görülmüştür.

Tablo 6. Tire Kazası Vakıf Arazilerinin Gelirleri ve Giderleri

\begin{tabular}{|l|c|}
\hline \multicolumn{1}{|c|}{ Açıklama } & Muaccele Kuruş \\
\hline Der uhde-1 ali ağa-1 tarla? kit'a 1 dönüm 8 & 00600 \\
\hline Der uhde-1 hacı Himmet tarla dönüm 5 & 02000 \\
\hline Der uhde-1 Kara Ali Ağa Tarla dönüm 5 & 00580 \\
\hline Der uhde-1 Süleyman efendi tarla kıt'a 1 dönüm 20 & 03000 \\
\hline Der uhde-1 Hasan efendi tarla kıt'a 1 dönüm 6 & 02050 \\
\hline (Toplam) & $\mathbf{8 2 3 0}$ \\
\hline Der uhde-1 Emine hatun tarla kit'a 1 dönüm 5 & 00700 \\
\hline Der uhde-1 Mehmed ağa tarla kıt'a 1 dönüm 5 & 00200 \\
\hline Der uhde-1 Osman Çavuş tarla kit'a 1 & 00300 \\
\hline Der uhde-1 Mustafa ağa tarla kit'a 1 dönüm 6 & 01750 \\
\hline Der uhde-1 Mustafa ağa tarla kıt'a 1 & 01500 \\
\hline Der uhde-1 ali ağa tarla kit'a 1 dönüm 5 & 01900 \\
\hline (Toplam) & $\mathbf{1 4 5 8 0}$ \\
\hline Hisse-1 kit'abet ve cibayet & 00364.5 \\
\hline (Kalan) & $\mathbf{1 4 2 1 5 . 5}$ \\
\hline nisf-1 dellaliye ve tam-1 ihbariye & 00291 \\
\hline (Kalan) & $\mathbf{1 3 9 2 4 . 5}$ \\
\hline humsu ${ }^{14}$ & 02784.5 kuruş 48 para \\
\hline (Kalan) & $\mathbf{1 1 1 3 9 . 5}$ kurus 12 para \\
\hline
\end{tabular}

Tablo 6'da mezkur kazanın arazi gelirleri, bu gelirlerin elde edildiği arazilerin miktarları ve gelirlere bağlı olarak hesaplanan giderlerin kayıt altına alındığı görülmektedir. Belgeye göre bu kısımdaki arazi gelirleri, dönüm ve kıt'a ölçü birimi üzerinden kaydedilmiştir.

Bilgiler kayıtlanırken, merdiven sistemi yöntemi ile ara ve genel toplamlar alınmıştır. Öncelikle beş arazinin peşin bedellerinin toplamı 8.230- Kuruş olarak kayıtlanması sonrasında diğer altı arazinin kaydı da ilave edilerek genel toplam alınmıştır. Bu toplam muaccel denen peşin ödenmesi gereken tutarı göstermektedir. Bedellerin genel toplamından kıt'abet yani yazışmaları ve hesaplamaları yapan katibe yani muhasebeciye ve cibayet işini yapan cabinin yani tahsildarın hissesi olan 364,5- kuruş ayrılmış ve kalan tutar 14.215,5- kuruş olarak hesaplama yapılmıştır. Yine bu tutardan tellaliye ve ihbariye bedelleri olan 291- kuruş düşülerek yeniden 13.924,5- kalan hesaplandığı görülmüștür.

\section{Tablo 7. Ferăg ve Arazi Gelirlerinin İcmali}

\begin{tabular}{|l|r|}
\hline Bera-yı hasılat-1 harc-1 ferağ an vakf-1 şerif-1 müşarünileyh hasılat & 2161 \\
\hline Hisse-1 kıt'abet ve cibayet & 0540 \\
\hline (Kalan) & $\mathbf{1 6 2 1}$ \\
\hline Humsu & 324 kuruş 24 para \\
\hline Yekün & $\mathbf{1 2 9 6 . 5}$ kuruş 36 para \\
\hline
\end{tabular}


Tablo 7'de görüleceği üzere vakıf arazi gelirlerinden sonra ferağ gelirleri de ayrıca 2.161- kuruş olarak kayıt altına alınmıştır. Bu durum, daha önceki kayıtta sadece ferağ bedellerinin hangi bedellerden alındığı ayrıntılı bir şekilde belirlenmesine rağmen bu kısımda icmal şeklinde tekrardan kayıtlanmıştır. Buradaki amaç, aslında ferağ bedellerinden vakfa aktarılan geliri tespit etmektir. 540kuruş kâtip ve cabi hisselerinden sonra 1.621- kuruş bakiye vermiş ve bunun da hums olarak hesaplanan beşte biri 324- kuruş 24 para olarak muhasebeleştirilmiştir. Ferağ bedellerinden kalan 1.296,5- kuruş 36 para ile arazi gelirlerinin 1.1139,5- kuruş 12 para toplanıp 1.2436- kuruş 48 para olarak toplam tutar hesaplanmıştır.

Tablo 8. Vakıfların Ferağ ve İntikalatların Müfredatları

\begin{tabular}{|l|c|}
\hline \multicolumn{1}{|c|}{ Açıklama (Vakıflar) } & Hasılat (kuruş) \\
\hline An vakf-1 Kazirzade & 022.5 \\
\hline An vakf-1 Hasan Çelebi & 100 \\
\hline An vakf-1 Kazirzade & 015 \\
\hline An vakf-1 Hafsa Hatun & 050 \\
\hline An vakf-1 Hasan Çelebi & 009 \\
\hline (Toplam) & $\mathbf{1 9 6 . 5}$ \\
\hline An vakf-1 Yahşi Bey & 082.5 \\
\hline An vakf-1 İbn-1 Melek & 045 \\
\hline An vakf-1 Hasan Çelebi & 015 \\
\hline An vakf-1 Cami-1 Yahya Fakih & 0157 \\
\hline (Toplam) & $\mathbf{4 9 6}$ \\
\hline Hums & 099 kuruş 24 para \\
\hline (Kalan) & $\mathbf{3 9 6 . 5}$ kurus 36 para \\
\hline
\end{tabular}

Belgenin devam eden kısmında ferağ bedellerinin, çalışanların maaşlarının müfredat (detaylı) kayıtları şu şekilde ifade edilmiştir; "Bera-yı Hasılat-ı harç-ı ferăg ve intikalat-ı mahlülat ve harc-ı muhasebat an evkaf-ı şerife-ı mezkurin der kaza-ı Tire der liva-ı Aydın be-nezaret-ı evkaf-ı hümayun ilhak şode ki, hasılat-ı mezkure der zaman-ı Bekir Usta müdir-ı evkaf-ı hümayun ber-muceb-ı mümza defter-ı müfredat ve ba-ferman-ı sami" önce Kazadaki vakıfların ferağ ve intikalatı "Bera-yı hasılat-ı harc-ı ferağ ve intikalat an evkaf-ı şerif-ı mezkurin der kaza-ı m." Bu durum aşağıdaki Tablo 8'de gösterilmiştir. Tablo 8'e göre vakıf ferağ ve intikalatları daha önce (tablo 4) kayıtlanmıştı. Ancak belgede tekrardan giderlerle birlikte gösterilmiştir.

Tablo 8'e göre bu kısımda sadece hums bedeli olarak 99- kuruş 24 para hesaplanmış ve kalan tutar 396,5- kuruş ve 36 para olarak muhasebeleştirilmiştir.

Belgenin devam eden kısmında "Bera-yı maaş-ı mücerred ve resm-ı adi ve nısf-ı dellaliye an evkaf-ı şerif-ı mezkûr" ifadesi ile net maaş-1 mücerred, resm-1 adi ve dellaliye bedelleri kayıtlanmıştır. $\mathrm{Bu}$ durum aşağıdaki Tablo 9'da verilmiştir. Belgenin bu kısmında Tire Kazası vakıflarının maaş-1 mücerred, resm-1 adi, nısf-1 dellaliye bedellerinin muhasebe kayıtları yer almaktadır.

Tablo 9. Vakıflara Ait Maaş, Resm-i Adi ve Dellaliye Kayıtları

\begin{tabular}{|c|c|c|c|c|c|c|}
\hline \multirow[b]{2}{*}{ Acıklama (Vakıflar) } & \multicolumn{2}{|c|}{ Maaș-1 Mücerred } & \multicolumn{2}{|c|}{ Resm-I Adi } & \multicolumn{2}{|c|}{ Nisf-ı Dellaliye } \\
\hline & Kuruş & Para & Kuruş & Para & Kuruș & Para \\
\hline An vakf-1 Hoca Kemal & 577 & 15 & 135 & 00 & 27 & 00 \\
\hline An vakf-1 Yahşi Bey & 748 & 15 & 175 & 00 & 35 & 00 \\
\hline An vakf-1 Latif Paşa & 384 & 20 & 090 & 00 & 18 & 00 \\
\hline An vakf-1 Yahşi Bey & 1036 & 30 & 242,5 & 00 & 48 & 00 \\
\hline An vakf-1 Yahşi & 0261 & 00 & 060 & 00 & 12 & 00 \\
\hline (Ara toplam) & 3007 & 30 & 702,5 & $\mathbf{0 0}$ & 140 & $\mathbf{0 0}$ \\
\hline An vakf-1 Yahşi Bey & 330,5 & 15 & 075 & 00 & 015 & 00 \\
\hline An vakf-1 Hafsa Hatun & 876 & 30 & 205 & 15 & 041 & 00 \\
\hline An vakf-1 şehr be Ahmed Bey & 235 & 15 & 055 & 00 & 011 & 00 \\
\hline
\end{tabular}




\begin{tabular}{|l|c|c|c|c|c|c|}
\hline An vakf-1 Yahşi Bey & 363 & 45 & 085 & 00 & 017 & 00 \\
\hline An Vakf-1 Yahya Bey & 705,5 & 00 & 165 & 00 & 033 & 00 \\
\hline An Vakf-1 Hasan bin Maslak? Bey & 363 & 45 & 085 & 00 & 017 & 00 \\
\hline (Toplam) & $\mathbf{5 8 8 1 , 5}$ & $\mathbf{0 0}$ & $\mathbf{1 3 7 2 , 5}$ & $\mathbf{1 5}$ & $\mathbf{2 7 4}$ & $\mathbf{0 0}$ \\
\hline
\end{tabular}

Tablo 9'dan da anlaşılacağı üzere maaş-1 mücerred toplamı 5881,5- kuruş, vergiler toplamı 1372,5- kuruş ve tellaliye toplamı ise 274- kuruş olarak kaydedilmiştir. Belgede kayıtlı bu toplamlar ayrıca ceman şeklinde 7.528 kuruş- 15 para ve humsu ise 1.505 kuruş- 27 para şeklinde kayıtlanmıştır. Kalan tutar da 6.022,5 kuruş- 48 para olarak muhasebeleştirilmiştir.

Çalışmaya konu olan belgenin devam eden kısmında "Bera-yı Maaş-ı mücerred ve harc-ı muhasebat an evkaf-ı şerif-ı mezkurin" olarak vakıfların maaş ve muhasebe harçlarının kayıtları yer almaktadır. Bu durum Tablo 10'da verilmiştir.

Belgenin son sayfası olan bu kısımda bazı toplama hatalarının yer aldığı görülmektedir. Bunlardan birincisi ara toplam olan 1.292 kuruş 48 para olan maaş-1 mücerred, aslında 1.172 kuruş 48 para olmalıyd. Ara toplam 120 kuruş fazla hesaplanmıştır. İkinci ara toplam, 4.736 kuruş 48 para olarak kayıtlanmış iken, aslında birinci ara toplamın hatasız hali ile 4.716 kuruş 48 para olmalıydı. İkinci ara toplam ile 100 kuruşluk birinci toplam düzeltilmesine rağmen hala 20 kuruşluk bir hatanın devam ettiğini söylemek mümkündür. Belgede üçüncü ara toplam 6.353 kuruş 48 para olarak kaydedilmiş iken aslında bu tutar 6.334 kuruş 48 para olmalıydı. Bu ara toplam ile 1 kuruşluk hata düzeltilmesine rağmen, 19 kuruşluk hatanın devam ettiği görülmektedir. Son toplam ise 8.907 kuruş 48 para olarak kayıtlanmış iken, aslında 8.888 kuruş 48 para olmalıydı. Son toplamda da 19 kuruşluk hatanın düzeltilmediği görülmektedir. Belgeye göre son toplam olan 8.907 kuruş 48 para üzerinden hums hesaplaması da hatalı gerçekleştirilmiştir. 1.681 kuruş 52 para olan hatalı tutarın toplamdan düşüldügü ve 7.225 kuruş 46 paralık tutarın kalan olarak belgede kayıt altına alındığ görülmüsstür. Belgeye göre harc-1 muhasebat kısmının birinci ara toplamı, 370,5 kuruş 15 para, ikinci ara toplamı $1.256,5$ kuruş 15 para, üçüncü ara toplam 1.660,5 kuruş 15 para, ve son toplam ise 2.299,5 kuruş 35 para olarak toplam alındığ1 görülmektedir. Bu tutardan hums olan 459 kuruş 35 para düşülmüş ve 1.839 kuruş 40 paranın kalan tutar olarak kaydedildiği görülmüştür. 459 kuruş 55 para müfettiş payı da son toplamdan çıkarılarak 1.379,5 kuruş 45 para toplam olarak muhasebeleştirilmesi sonrası "Cem'i emtia zamm-eş" ile 459 kuruş 55 kuruş yeniden ilave edildiği görülmüsstür. Bütün bunlar sonrası belgenin son kısmındaki gelirler toplamı 15.484 kuruş 50 para olarak kayıtlanmıştır. Ancak, burada da bir hata söz konusudur. Asıl toplam, hesap hataları düzeltilmesi sonrasında 16.592 kuruş 41 para olarak kayitlanmas1 gerekiyordu. Belgenin son kısmında ceman yekün olarak belgenin gelirlerinin toplamı gösterilmiştir. Ancak burada bir hatanın (belge tutarlarına göre) söz konusu olmadığını söylemek mümkündür.

Tablo 10. Vakıfların Maaş-ı Mücerred ve Harc-Muhasebat Kayıtları

\begin{tabular}{|c|c|c|c|c|}
\hline \multirow[b]{2}{*}{ Açıklama (Vakıflar) } & \multicolumn{2}{|c|}{ Maaş-ı Mücerred } & \multicolumn{2}{|c|}{ Harc-ı Muhasebat } \\
\hline & Kuruş & Para & Kuruş & Para \\
\hline An vakf-1 Bayram kethüda & 040 & & 010 & \\
\hline An vakf-1 Hafsa hatun & 260 & & 090 & \\
\hline An vakf-1 Mehmed Ali Ağa & 524 & & 136 & \\
\hline An vakf-1 Şehr-be Mehmed Bey & 200 & & 100 & \\
\hline An vakf-1 Yahşi Bey & 148 & 48 & 034,5 & 15 \\
\hline (Ara Toplam) & 1292 & 48 & 370,5 & 15 \\
\hline An vakf-1 Hafsa Hatun bint-1 Aydın Bey & 2400 & & 600 & \\
\hline An vakf-1 İbn-1 Melek & 0544 & & 136 & \\
\hline Van vakf-1 Ayas? Bey & 0480 & & 120 & \\
\hline An vakf-1 Küçük? Hafiz & 0016 & & 004 & \\
\hline
\end{tabular}




\begin{tabular}{|c|c|c|c|c|}
\hline An vakf-1 Yahya Ağa & 0104 & & 026 & \\
\hline (Ara Toplam) & 4736 & 48 & 1256,5 & 15 \\
\hline An vakf-1 Hafsa Hatun & 1420 & & 0355 & \\
\hline An vakf-1 ma-1 leziz-1 Alaaddin & 0018 & & 0004 & \\
\hline An vakf-1 Arnavut Kadın? & 0080 & & 0020 & \\
\hline An vakf-1 Kara Hayreddin & 0020 & & 0005 & \\
\hline An vakf-1 Karizzade & 0080 & & 0020 & \\
\hline (Ara Toplam) & 6353 & 48 & 1660,5 & 15 \\
\hline An vakf-1 Kara Peşkiri? & 1600 & & 0400 & \\
\hline An vakf-1 Latif Paşa & 0336 & & 0084 & \\
\hline An vakf-1 Hasan Celebi & 0144 & & 0036 & \\
\hline An vakf-1 Hacı Liyaf? & 0200 & & 0050 & \\
\hline An vakf-1 (.....) & 0006 & & 0001,5 & \\
\hline An vakf-1 nükud-1 (...) & 0108 & & 0027 & \\
\hline An vakf-1 Mehmed Ağa & 0160 & & 0040 & \\
\hline An vakf-1 Cami-1 Serif & 0000 & & 0000 & \\
\hline (Toplam) & 8907 & 48 & 2299,5 & 15 \\
\hline Humsu & 1681 & 52 & 459 & 35 \\
\hline (Kalan) & 7225 & 46 & 1839 & 40 \\
\hline Rub' hisse ma'a emtia-1 muhasebat aid-1 müfettiș-1 evkaf & & & 459 & 55 \\
\hline (Kalan) & & & 1379,5 & 45 \\
\hline Cem'i emtia zamm-eş & & & 459 & 55 \\
\hline (Toplam) & & & 1839 & 40 \\
\hline Yekün & 15484 kuruş 50 para & & & \\
\hline Ceman Yekün & 27920,5 kuruş 38 para & & & \\
\hline
\end{tabular}

Belgenin kapanış kaydı ise şu şekildedir; "Ferman-ı samileri buyurulduğu üzere meblăg-ı hasılat ve muaccelat-ı mezkur hesab olundukda bu miktara bali olmuş olmasıyla meblağ-ı mezbur yirmi yedi bin dokuz yüz yirmi buçuk kuruş otuz sekiz akçenin tahsilat odasindan zimemat pusulalarının tahriri babında ferman hazret-ı menlehü'l-emrindir." "Fi 7 C. Sene 1275" "Varidat derkenarı natı olduğu üzere meblağ-ı hasılat-ı mezkûrun tahsili babında zimmet pusulası yazllmuştır." "Fi 20.Z. sene 1275".

Vakıflar ile ilgili başlıca bilgiler genellikle vakfiyeler, şer'iyye sicilleri, mühimmeler, ahkam ve şikayet defterleri, tahrir defterleri ve vakıf muhasebe defterlerinde bulunmaktadır (Orbay, 2004: 290). Vakıfların muhasebe defterleri, vakıfların gelirlerinin hangi kaynaklardan elde edildiğinin yanı sıra, elde edilen gelirlerin nerelerde tüketilerek gidere dönüştürüldüğünün de gösterildiği defterlerdir. Vakıf defterleri sayesinde vakıfların mali gücü hakkında, gelir ve giderlerinin zaman içerisindeki değişimlerini tespit etmek mümkündür. Bunun yanında vakıf muhasebe defterleri sayesinde çalışanların kimler olduğu ve bu kişilere ödenen personel giderlerinin de tespiti de mümkün olmaktadir.

\section{SONUÇ}

Bu çalışmada, vakıf muhasebe defterlerinden EV.d./15477-0-0 kodlu ve 07.06.1275 (H.) tarihli belge Başbakanlık Osmanlı Arşivlerinden elde edilerek çözümlenmesine çalışılmıştır. Defterde Osmanlı Devleti dönemlerinde zengin tarım arazileri olan Aydın Sancağı Tire Kazası'nda faaliyet göstermiş olan vakıfların muhasebe kayıtları yer almaktadır. Öncelikle belgenin vakıf defterlerinin temel özelliği olan açılış kaydı ile başladığı görülmüştür. Belgedeki açılış kaydı sonrasında yer alan birinci kayıtta, "Nezaret-i mezkurede evkaf-l şerifelerin yetmiş senesine mahsuben rüyet olunan muhasebatın miktarı", ikinci kayıtta, "Mülhakat-ı evkaftan vuku bulan mahlulatın miktarı", üçüncü kayıtta "Kaza-ı mezkûrda vaki mazbut evkaftan cennet-mekân sultan selim han tabe-serahu hazretlerinin darülkurra evkaf-ı şerifi arazilerinden vukubulan mahlulat bi'l-müzayede füruht olunan tarlahanın? miktarı", dördüncü kayıtta "Mülhakat-ı evkaftan vukubulan ferağ ve intikalatın miktarı" beşinci kayıt "Mazbut evkaftan cennet mekân Firdevs Aşiyan Sultan Selim Han hazretlerinin kaza-ı mezkûrda olan arazilerinin feră̆ ve intikallerinin miktarını mübeyyin defteridir." açıklaması ile muhasebe işlemlerinin gerçekleştirildiği tespit edilmiştir.

Söz konusu belgenin yapılan çözümlenmesi sonucunda her bir kayıt ile ilgili bilgilerin gerek açılışlarında ve gerekse de tutarlarının yanlarında kaynağının ve açıklamasının yazılı olması, muhasebenin temel kavramlarından tam açıklama kavramına işaret etmektedir. Belgede yer alan kayıtların belirli bir dönemi kapsadığını anlatmak için tarihleri verilerek yazılması ise temel 
kavramlardan dönemsellik kavramına ve her bir açıklamanın tutarlarının o günkü para birimi ile kayıt altına alınmas1 da yine temel kavramlardan para ile ifade edilebilme kavramını ifade etmektedir. Diğer taraftan vakfin ana faaliyet konusunun halk/toplum olması sebebiyle yapılan bütün muhasebe işlemlerinin yine temel kavramlardan sosyal sorumluluk kavramına karşılık gelirken, yapılan her bir kaydın bir belgesinin olması ve vakıf defterlerinde bu belgelerin yer alması ise temel kavramlardan tarafsızlık ve belgelendirme kavramını işaret etmektedir.

\section{KAYNAKÇA}

AKÇAY, S. "Merdiven Yöntemi ve Çift Taraflı Kayıt Yöntemi Ekseninde Devlet Muhasebesinin Gelişimi (1299-2017)", Ulakbilge, 5(17), 1875-1894.

AYDEMIR O. ERKAN M. (2011). Merdiven Kayıt Yöntemi ve Günümüz Muhasebe Sistemi, Muhasebe ve Finans Tarihi Araştırmaları, (1), 110-128.

BARKAN Ö. L., (1963). “Osmanlı İmparatorluğunda İmaret Sitelerinin Kuruluş ve İşleyiş Tarzına Ait Araştırmalar”, İstanbul Üniversitesi İktisat Fakültesi Mecmuas1, 23(1-2): 239-296.

Başbakanlık Osmanlı Arşivleri EV.D.../15477-0-0 Kodlu Defter.

CAN A. V., ZEYTIN M. (2010). "Osmanlı Dönemine Vakıf Muhasebesi ve Elvan Bey Oğlu Sinan Bey Vakfı Örneği”, 8. Türk Dünyası Sosyal Bilimler Kongresi, 485-495.

DURMUŞ M. E., BEKTAŞ İ. (2017). “Osmanlı'da Muhasebe Usulu ve Vakıf Muhasebe Kayıtları Okuma Kılavuzu”, PESA Uluslararası Sosyal Araştırmalar Dergisi, 3(2): 196-208.

ELITAŞ C., GÜVEMLİ O., AYDEMIR O., ERKAN M., ÖZCAN U., OĞUZ M., (2008), Osmanl1 İmparatorluğunda 500 Y1l Boyunca Kullanılan Muhasebe Yöntemi: Merdiven Yöntemi, Ankara.

EROL, M. ELAGÖZ İ. ÖZTÜRK S. (2012). Tarih Boyunca Muhasebe Uygulama ve Eğitim Araçları, Muhasebe ve Finans Tarihi Araştırmaları Dergisi, (2), 221-232.

GÜVEMLİ O., (2014), Osmanlı'da Devlet Muhasebesi Mesleğinin Özellikleri, Muhasebe ve Finans Tarihi Araştırmaları Dergisi, Ocak Sayısı, 227-233.

GÜVEMLİ O., GÜVEMLİ, B. (2016). "Osmanlı Kayıt Kültüründe Vakıf Muhasebesi ve Devlet Muhasebe Sistemi”, Vakıflar Dergisi, 45: 9-21.

FERAĞ, Türkiye Diyanet Vakfi İslam Ansiklopedisi, C.12, s.393, http://www.islamansiklopedisi.info/dia/pdf/c12/c120199.pdf.

KURT İ., Para Vakıflarının Muhasebesi, www.isav.org.tr/img/20140225_2782251239.pdf, erişim: 01.01.2019.

MAZENDERANI A. Çev. OTAR, İ. (2013), Risale-i Felekkiye, Kitab-us Siyakat, Ed. Oktay Güvemli, Cengiz Toraman, Batuhan Güvemli, İstanbul.

ÜLKER Y., TORAMAN, C. (2012), “Osmanlı Devleti'nin Sosyal ve Ekonomik Hayatında Para Vakıflarının Rolü ve Muhasebe Uygulamaları, Manas Sosyal Araştırmalar Dergisi, 1(2): 55-84.

ORBAY K., (2004), Vakıf Muhasebe Defterlerinde Ayni Toplanan Tarımsal Gelirler ve Ayni Giderlerin Fiyatlandırılması ve Tarihsel Fiyatlar Endekslemeleri Konusunda, Osmanlı Araştırmaları, XXIV: 289-301.

ORBAY K., (2005), Vakıfların Bazı Arşiv Kaynakları, Vakıflar Dergisi: XXIX, 27-41.

ÖZÇELIK KATKAT M. (2017), Türk Muhasebe Sisteminin Gelişiminde Vergi Etkisi, Akademik Bakış Dergisi, 60, 396-413.

ÖZTÜRK, S. (1994). Osmanlı Belgelerinde Siyakat Yazısı, Başbakanlık Devlet Arşivleri Genel Müdürlüğü Osmanlı Daire Başkanlığı Yayın No: 18, Ankara.

ÖZTÜRK S. (1996), Osmanlı Arşiv Belgelerinde Siyakat Yazısı ve Tarihi Gelişimi, İstanbul. 
ÖZERHAN Y., ERKAN M., NAZLIOĞLU B., (2013), "Osmanlı Arşivinde Merdiven Yöntemi ile Yazılmış Muhasebe Defter ve Raporları”, Muhasebe ve Finans Tarihi Araştırmaları Dergisi, 5, $88-120$.

SEMİZ Y., (2016). “Osmanlı Devleti'nde Para Vakıfları”, Selçuk Üniversitesi Sosyal Bilimler Meslek Yüksekokulu Dergisi, 19(1): 89-101.

SIRIM V., (2017). "Bir Finansman Kaynağı Olarak Vakıflar, Osmanlı Örneği”, İnsan ve Toplum Bilimleri Araştırmaları Dergisi, 6(6): 173-188.

ŞENSOY F. (2014). Muhasebe Defterlerinden Vakıfların Çok Yönlü Boyutlarını İzlemek-Bir Örnek XVII Y.Y., Temmuz Sayıs1, 76-103.

ÇAPKINER E. ATAİ G. (2015). Kıbrıs'ta Muhasebenin Tarihsel Gelişim Evreleri ve Dünyada Uluslararası Finansal Raporlama Standartları, WORD of IFRS, Ekim 2015-Özel Say1, 55-88.

TÜRKÇE SÖZLÜK, (2011). Türk Dil Kurumu Yayınları, Ankara.

YENER M.S. (1995). Vakıf Hukukunda Mahluliyet, Türkiye Barolar Birliği Dergisi, (1), 87-91.

\section{Ek 1:}

Bera-yı hasılat-ı harç-ı ferăg ve intikalat ve muaccelat-ı mahlulat-ı an vakf-ı şerif-ı Sultan Selim Han der kaza-ı Tire der liva-ı Aydın an makbuz-ı hazine-ı evkaf-ı hümayun vacib der sene [boşluk] der zaman-ı Bekir Usta Müdir-ı Evkaf-ı Liva-ı Sabık ber muceb-ı mümzü defter-ı müfredat ve ba-ferman-ı sami", "Bera-yı hasılat-ı muaccelat-ı mahlulat an vakf-ı müşarunileyh der kaza-ı m. der liva-ı m.", iken, yedinci kaydın açıklaması B"era-yı Hasılat-ı harç-ı ferağ ve intikalat-ı mahlülat ve harc-ı muhasebat an evkaf-ı şerife-ı mezkurin der kaza-ı Tire der liva-ı Aydın be-nezaret-ı evkaf-ı hümayun ilhak şode ki, hasılat-ı mezkure der zaman-ı Bekir Usta müdir-ı evkaf-ı hümayun ber-muceb-ı mümza defter-ı müfredat ve ba-ferman-ı sami" önce Kazadaki vakıfların ferağ ve intikalatı "Bera-yı hasılat-ı harc-ı ferağ ve intikalat an evkaf-ı şerif-ı mezkurin der kaza-ı m" şeklinde yer aldığı görülmüştür. Belgenin son kısımlarında maaş, resim ve dellaliye miktarları ise "Bera-yı maaş-ı mücerred ve resm-ı adi ve nısf-ı dellaliye an evkaf-ı şerif-ı mezkûr" ve "Bera-yı Maaş-ı mücerred ve harc-ı muhasebat an evkaf-ı şerif-ı mezkurin" şeklinde yer alan açıklamalar ile kayıt alındığı görülmüştür. Belgenin kapanış kaydı ise "Ferman-ı samileri buyurulduğu üzere meblă̆-ı hasılat ve muaccelat-ı mezkur hesab olundukda bu miktara balı olmuş olmasıyla meblağ-l mezbur yirmi yedi bin dokuz yüz yirmi buçuk kuruş otuz sekiz akçenin tahsilat odasından zimemat pusulalarının tahriri babında ferman hazret-l menlehü'l-emrindir." "Fi 7 C. Sene 1275" "Varidat derkenarı natık olduğu üzere meblağ-ı hasılat-ı mezkûrun tahsili babında zimmet pusulası yazllmıştır. Fi 20.Z. sene 1275" 